\title{
Market Development Approach: A New Paradigm in Promoting Business Development Services
}

\author{
Rabindra Kumar Neupane ${ }^{(1)}$
}

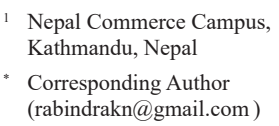

Nepal Commerce Campus, Kathmandu, Nepal

* Corresponding Author (rabindrakn@gmail.com)

Received: 25 August, 2021

Revised: 9 October, 2021

Accepted: 13 November, 2021

Published: 25 December, 2021

How to cite this paper:

Neupane, R.K. (2021). Market development approach: A new paradigm in promoting business development services. Quest Journal of Management and Social Sciences, 3(2), pp. 291-306.

Copyright (C) 2021 by authors and Quest Journal of Management and Social Sciences.

This work is licensed under a Creative Commons Attribution-Non Commercial-No Derivatives 4.0 International License.

https://creativecommons.org/ licenses/by-nc-nd/4.0/

\begin{abstract}
Background: Business Development Service (BDS) market development approach is considered as a paradigm shift to traditional approaches in promoting and delivering enterprise support services. BDS is an internationally recognized tool to achieve economic prosperity through the development of Micro, Small, and Medium Enterprises (MSMEs). Most developed and developing nations are promoting BDS for MSME development and employment generation. MicroEnterprise Development Program (MEDEP) has initiated the BDS market development approach named as Micro-Enterprise Development (MED) model in Nepal since1998.
\end{abstract}

Objective: This article is objectively written to analyze and present the MED model, implementation approach, and MEDEP's strategies for effective BDS delivery; market development; and sustainability.

Method: Secondary as well as primary sources of information have been used to collect data. Secondary data have been triangulated through experts' opinions. A descriptive methodology has been used while analyzing data.

Result: Apart from ME promotion, this article has also briefly presented how MEDEP has contributed to making an enabling environment for sustainable BDS market development in Nepal. MED model was implemented by MEDEP in 10 districts in its first phase (1998-2003). The model is found successfully implemented in all districts of Nepal till the end of MEDEP's 4th phase in 2018. It is in the process of being replicated in all 753 Local Governments (LGs).

Conclusion: MEDEP remarkably found highly contributed to the introduction, development, and growth of the BDS market development approach in Nepal by creating more than 132,000 micro-enterprises, developing institutional frameworks and partnerships modality for service delivery, and creating an enabling policy environment. This approach is found well recognized and replicated in some manner by other government, Non-Government and private BDS providing institutions as well.

Paper Types: Research Paper

Key Words: BDS, Market Development Approach, Micro-enterprises, MicroEnterprise Development (MED)

JEL Classification: M2 


\section{Introduction}

In its published guideline in 2001, the Committee of Donor Agencies for Small Enterprise Development (CDASED) has included training, consultancy and advisory services, marketing assistance, information service, technology development and transfer, and business linkages are general components of Business Development Services (BDS) for assisting Micro, Small, and Medium Enterprises (MSMEs) development. According to the ILO BDS Seminar Reader (2004; cited by Eiligmann, 2005), BDS projects are increasingly becoming part of broad development initiatives as the most important trend during the past years. According to Altenburg and Stamm (2004), various projects and programs implemented by the international donor communities operate with a wide range of different BDS (p.11). BDS is generally regarded as a non-financial service and aimed to improve the performance of an enterprise, its access to markets, and its ability to compete.

Bajracharya et al. (2005) have stated that although varieties of agencies are there in Nepal to provide education and skill training at various levels but exist very limited BDS providers apart from the Department of Cottage and Small Industries (DCSI), Cottage and Small Industry Development Board (CSIDB) and other few project-based agencies (p.27). This indicates the availability of agencies offering several standalone skill and entrepreneurship development services but lacking a holistic BDS approach for enterprise development in Nepal. Eligmann (2005) has stated that direct provisioning of BDS services by public and funding agencies had resulted in weak performance and low enterprise sustainability. Therefore, in the late 1990s, the focus moved towards promoting commercially oriented markets for BDS by shifting service provision to private sector actors (p.5). Various studies admitted that the credit of this shift goes to the recommendation of CDASED, known as a new paradigm for BDS market development. Nepal initiated the BDS modality for micro-enterprise creation and development for poverty alleviation through Micro-Enterprise Development Program (MEDEP) in 1998 (Thapa \& Mathema; 2001). Concerning the above background information, the study is objectively focused on analyzing the progress made in adopting a holistic enterprise development approach and BDS market development in Nepal.

Davis and Vladica (2005) have stated that micro-enterprises (MEs) face numerous obstacles to growth that cannot be overlooked since they play a great role in economic development. OECD (2017) suggested that the proper promotion of MSMEs requires a conducive business environment to remove their growth barriers. The findings of studies on MSMEs have commonly agreed that (i) MSMEs are the economic backbone of a country; (ii) promotion of MSEs is challenged by various obstacles directly related to enhancing their competency for growth and sustainability; and (iii) need to promote of MSMEs has been advocated and applied as an important economic development strategy by various nations. To support SMEs in countering their growth problems, increasing their flexibility, and reducing cost. Altenberg and Stamm (2004) have stated that during the last few years as opposed to traditional enterprise development models, a new paradigm has emerged concerning who should provide these business development services and how these services are to be provided. The main contributions to this new paradigm have come from CDASED in 2001. (p. 6). From the above statements, this article has focused on the issues on how Nepal has progressed towards the adoption of the new BDS market development approach for enterprise development that is said to be a combination of various enterprise support services offered holistically for enterprise development.

This article will be very beneficial for students by helping them acquire knowledge on MED modality so that they can grab enterprise development opportunities made available in their locality. This article will be equally significant to skill training and enterprise support agencies to be informed on enterprise growth stages, have compliance of their services according to issues or problems entrepreneurs face in different stages of enterprise growth, and be competitive for offering demand-based BDS. Existing and future entrepreneurs can be also advantaged by knowing growth stages and services available through 
the MED modality. Program evaluators and BDSPOs will also be cautious while evaluating the growth achieved by enterprises according to their nature and services, industrial competitiveness, conducive legal; political; and infrastructural environment as well as owner's intentions and motivational factors.

The rest of this study is organized as Section 2 covers a review of the literature followed by research methods. In section 4 data analysis and result is covered and finally section 5 concludes the study.

\section{Review of Literature}

\section{BDS Market Development Approach: A New Paradigm}

Studies of (Zeng et al., 2010; Knight; 2001 cited by Goyal, Sergi, and Esposito; 2015) have identified a long-established belief that Micro, Small, and Medium Enterprises (MSMEs) account for a majority of the businesses ( $90 \%$ or more) and employment (60\% to $90 \%$ ) thereby, exerting a major influence on the overall socio-economic growth and competitiveness of different countries. Therefore, countries make continuous efforts to encourage the establishment and growth of MSMEs by improvising policy-level initiatives, promoting cluster-based setups as well as facilitating business advice, training, and skillbuilding programs (p. 313). The above lines not only show the importance of promoting MSMEs to a country but also major elements required to develop a sustainable BDS market i.e., policies, programs and institutional set-ups. CDASED (2001) and most of the BDS evaluation studies and guidelines have revealed a limited impact on the government-funded business advisory services on the sustainability and growth of MSMEs. Studies have also identified that the outcome of direct BDS intervention by the government is less successful for creating a sustainable BDS market. Ultimately, studies have urged for replacement of traditional approaches of BDS to market development approach. That's why the mechanism of BDS delivery shifted to private institutions as a new paradigm.

CDASED (2001) has identified three key actors to deliver and promote BDS. i.e., (i) BDS providers (BDSPOs) or supply-side actors; (ii) Entrepreneurs who need BDS supports are at the demand side; and (iii) local or national level governments and donor agencies are known as BDS facilitators. To get rid of the negative sense of the term "Non-financial services", the term market development approach is started to use while promoting BDS. Their market development paradigm has advocated that BDS should not be delivered directly through government agencies and donors. Government and donors should act as facilitators by allowing funds to commercial BDS providers for effective service delivery. Rijneveld (2006) has conducted a sector analysis in BDS that has stated different stages of development in the BDS sector appeared from the late sixties. Many practitioners adhere to the broader definition of BDS because, according to their understanding, it relates more to the demand of MSMEs, and additionally permits them the flexibility to respond to the many constraints facing small businesses. Since the late 1990 s, the focus has been shifted to promoting commercially oriented markets to supply BDS by shifting service provision to private sector actors (Eiligmann, 2005; p. 5). This shift is also known as a new paradigm of BDS focused on the BDS market development as shown in Figure 1 below.

The market development approach of BDS has focused on the market sustainability of BDS. It has been suggested that the provision of services related to private goods should be left entirely to market forces, and the provision of services related to public goods should only be intervened by the donor and government agencies. In contrast to this, many authors and practitioners have indicated great challenges while making a clear distinction between private goods and public goods. Therefore, such challenges are viewed as shortcomings of the new paradigm of BDS by researchers.

In contrast to the market development approach of CDASED, many donors, practitioners, and authors realized that when it comes to targeting the poorest of the poor, in some cases, the livelihood development approach of BDS will be better. According to Eiligmann (2005), although the value of market development approach is widely recognized even in post-conflict areas and areas of efficiently 
delivering public services, depending on the social and economic contexts and the kind of services to be promoted, it is not always possible to do without subsidies in remote rural areas. In such situations, practitioners consider the Livelihood Development Services (LDS) model will more appropriately serve the poor.

Figure 1: Business Development Service (BDS) Market Development Approach
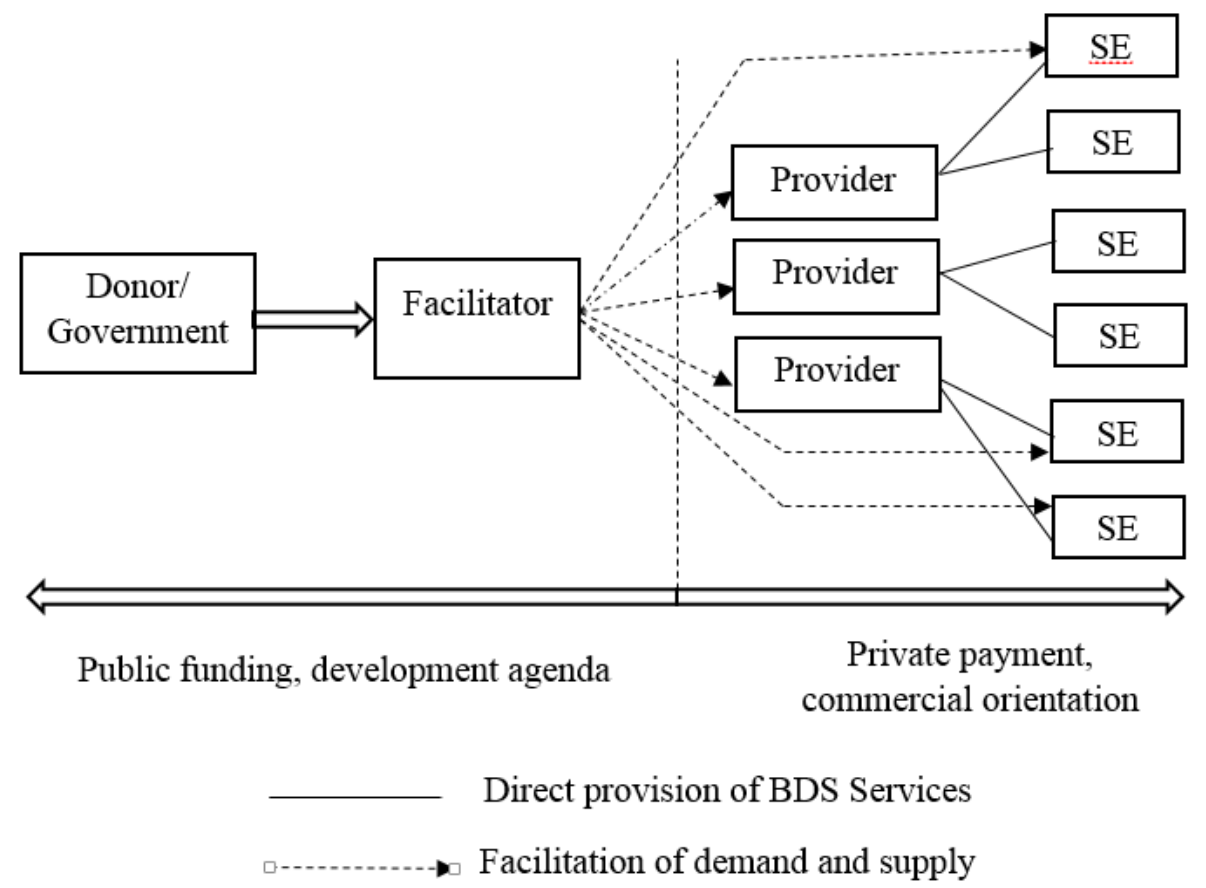

Note. A new market development approach for promoting BDS. From BDS for Small Enterprises: Guiding Principles for Donor Intervention (p.4), by CDASED, 2001

Altenburg and Stamm (2004) have noticed that although, the new paradigm of BDS shows that BDS systems should operate as closely as possible to the market if they are to avoid misallocation of resources, optimize cost-benefit ratios and avoid any crowding out of private service providers, yet it is still unclear how realistic the new paradigm is, and whether it will actually guide development cooperation towards more effective, efficient and sustainable interventions. They have argued that this new paradigm is too market-optimistic, underestimates the degree of market failure, and neglects the political dimension of service provision. They have also found that it is less helpful to the development practitioners in situations where there are blurred associations among 'private goods' and 'public goods'. They have also argued that the application of the new market development approach is limited by political interference, the existence of bureaucratic institutions that provide market-distorting service programs, and SME customers who are used to receiving free-of-cost government services.

\section{Problems and Issues Associated with Growth Stages of MSMEs}

To support SMEs development, an understanding of problems and issues associated with different enterprise growth stages is vital. It will help to design and implement the best supporting models for SMEs. Based on their experiences, empirical studies, and literature, Churchill and Lewis (1983) have developed a framework that is claimed to be more relevant to understand the growth stages and the general issues small businesses may confront during those stages. Table 1 highlights their framework of small business development. 
Table 1: Small business development framework and management factors by Churchill and Lewis

\begin{tabular}{|c|c|c|c|c|c|}
\hline \multirow[b]{2}{*}{$\begin{array}{l}\text { Stages of } \\
\text { Growth }\end{array}$} & \multicolumn{5}{|c|}{ Management Factors } \\
\hline & $\begin{array}{l}\text { Management } \\
\text { Style }\end{array}$ & $\begin{array}{l}\text { Organizational } \\
\text { Structure }\end{array}$ & $\begin{array}{l}\text { The extent } \\
\text { of Formal } \\
\text { Systems }\end{array}$ & $\begin{array}{c}\text { Major } \\
\text { Strategic } \\
\text { Goals }\end{array}$ & $\begin{array}{c}\text { Owner's } \\
\text { Involvement } \\
\text { in Business }\end{array}$ \\
\hline Existence & $\begin{array}{l}\text { Direct } \\
\text { supervision }\end{array}$ & Simple & $\begin{array}{l}\text { Minimal } \\
\text { to Non- } \\
\text { existence }\end{array}$ & $\begin{array}{l}\text { How to remain } \\
\text { alive }\end{array}$ & $\begin{array}{l}\text { Synonymous } \\
\text { with business }\end{array}$ \\
\hline Survival & $\begin{array}{l}\text { Major decision } \\
\text { making by owner }\end{array}$ & Simple & $\begin{array}{l}\text { Minimal, just } \\
\text { up to cash } \\
\text { forecasting }\end{array}$ & Survival & $\begin{array}{l}\text { Synonymous } \\
\text { with business }\end{array}$ \\
\hline $\begin{array}{l}\text { Success } \\
\text { Substage } \\
\text { III-D }\end{array}$ & $\begin{array}{l}\text { The takeover of } \\
\text { certain duties } \\
\text { of the owner } \\
\text { by functional } \\
\text { managers }\end{array}$ & $\begin{array}{l}\text { Basic } \\
\text { Functional units } \\
\text { exist }\end{array}$ & $\begin{array}{l}\text { Plan for cash } \\
\text { reserve to } \\
\text { withstand the } \\
\text { inevitable } \\
\text { rough times }\end{array}$ & $\begin{array}{l}\text { Maintaining } \\
\text { the status quo. }\end{array}$ & $\begin{array}{l}\text { Completely } \\
\text { or partially } \\
\text { disengage } \\
\text { from the } \\
\text { company }\end{array}$ \\
\hline $\begin{array}{c}\text { Success } \\
\text { Substage } \\
\text { III-G }\end{array}$ & $\begin{array}{l}\text { Delegated } \\
\text { operational } \\
\text { decisions to } \\
\text { managers, } \\
\text { strategic } \\
\text { directions by the } \\
\text { owner }\end{array}$ & $\begin{array}{l}\text { Structural } \\
\text { system based } \\
\text { on attention to } \\
\text { forthcoming } \\
\text { needs }\end{array}$ & $\begin{array}{l}\text { Operational } \\
\text { as in sub- } \\
\text { stage III-D } \\
\text { and extensive } \\
\text { strategic } \\
\text { planning }\end{array}$ & $\begin{array}{l}\text { Use all cash } \\
\text { and borrowing } \\
\text { power in } \\
\text { growth } \\
\text { financing }\end{array}$ & $\begin{array}{l}\text { Deep } \\
\text { involvement } \\
\text { in Strategic } \\
\text { planning, more } \\
\text { active in all } \\
\text { phases of the } \\
\text { company's } \\
\text { affairs }\end{array}$ \\
\hline Take-off & $\begin{array}{l}\text { Delegate } \\
\text { responsibility to } \\
\text { others, Investors } \\
\text { or creditors } \\
\text { controlled } \\
\text { decision making }\end{array}$ & $\begin{array}{l}\text { Decentralized; } \\
\text { Divisionalized }\end{array}$ & $\begin{array}{l}\text { More } \\
\text { refined and } \\
\text { extensive, } \\
\text { specialized }\end{array}$ & $\begin{array}{l}\text { Have enough } \\
\text { cash supply } \\
\text { to satisfy } \\
\text { demands that } \\
\text { growth brings }\end{array}$ & $\begin{array}{l}\text { Owner and } \\
\text { Business } \\
\text { become } \\
\text { reasonably } \\
\text { separate, yet } \\
\text { the company is } \\
\text { still dominated } \\
\text { by the owner's } \\
\text { presence and } \\
\text { stock control }\end{array}$ \\
\hline $\begin{array}{l}\text { Resource } \\
\text { Maturity }\end{array}$ & $\begin{array}{l}\text { Professionalized } \\
\text { decision-making } \\
\text { style by the } \\
\text { use of different } \\
\text { management } \\
\text { tools }\end{array}$ & $\begin{array}{l}\text { Decentralized, } \\
\text { Divisionalized }\end{array}$ & $\begin{array}{l}\text { Well- } \\
\text { developed } \\
\text { extensive } \\
\text { system }\end{array}$ & $\begin{array}{l}\text { Consolidation } \\
\text { and control of } \\
\text { financial gains } \\
\text { brought on by } \\
\text { rapid growth; } \\
\text { retain the } \\
\text { competitive } \\
\text { advantages of } \\
\text { small size }\end{array}$ & $\begin{array}{l}\text { Owner and } \\
\text { Business } \\
\text { are quite } \\
\text { separate both } \\
\text { financially and } \\
\text { operationally }\end{array}$ \\
\hline
\end{tabular}

Note. Compiled by the researcher. From Growing Concerns: The Five Stages of Small Business Growth (Churchill, Neil \&Lewis, 1983) Harvard Business Review (Churchill, Niel, \& Lewis, 1983) 
Although the above framework shows five stages of business growth, it has also explained that all businesses not necessarily be able to reach in peak stage. In general, it suggests that the inability to handle managerial factors effectively in respective growth stages, nature of product and services, industrial competitiveness, conducive legal, political, and infrastructural environments as well as owner's intentions, and motivational factors are very crucial to overcome growth challenges. The duration of each stage also vary accordingly depending upon the managerial capability of owners and the other available supporting environment. Despite these uncertainties, they have suggested that understanding such growth stages is certainly beneficial to entrepreneurs and management professionals, so that they can give proper attention to the demands of each growth stage and timely address the necessary challenges, and solve the problems as well. Therefore, we can understand that how well integrated BDS can serve as expert solutions to entrepreneurs at different stages of their business growth.

\section{Skill and Enterprise Development Practices in Nepal}

From ancient times, people of Nepal residing in various topographical areas are found well equipped with appropriate skills guided by their social and religious principles. The transfer of local skills is practiced from generation to generation. Nowadays, Nepal is also not independent from the effects of globalization and the shifts in the global society. Thus, it has come up with new anticipations. Societies are changing due to the availability of information, communication, and education. Demands of society are also shifting from traditional occupational skill training practices to commercial training packages. Such changes are demanding appropriate shifts in models and techniques of skill training and enterprise development support in Nepal. The cottage industry has been a part of Nepalese life, particularly the handicraft sector. In this sector, women have always been and still are largely involved. This sector does not demand high academic qualifications and offers flexible working hours and places (Basnet, 2001). As stated by Ranabhat (2007), the Department of Cottage and Small Industries (DCSI) has been focusing on its efforts towards creating enabling environment for utilization of locally available resources and skills to promote employment opportunities, and to create a sustainable industrial base in the kingdom (p. 176).

As an indication of great change appeared in Technical Education and Vocational Training (TEVT), separate technical schools were designed and established with the purpose to produce skilled workforce in (i) rural parts for agriculture, health, rural construction and mechanization; and (ii) urban parts for cottage and modern industries. (Ramse, 1993; Sharma, 1998 as cited by Kafle, 2007). After DCSI and CSIDB, Council for Technical Education and Vocational Training (CTEVT) has emerged as an important source of skill training (Bajracharya et al. 2005). CTEVT was established in 1989 to deliver short and long-term skill training courses and skill certification. (Kafle, 2007). Industrial Enterprise Development Institute (IEDI) is a semi-autonomous body under the Ministry of Industry (MoI). It has developed out of the Small Business Promotion Project (SBPP) in 1984 to promote entrepreneurship and small business in urban and semi-urban centers of Nepal (Gurung, 1999; Acharya et al., 1999). Micro-Enterprise Development Program (MEDEP) was initiated in 1998 as a flagship poverty reduction program of UNDP and the Nepal Government (UNDP, 2015). Later, MEDEP was funded by other international donors also. The Micro-Enterprise Development (MED) model of MEDEP is considered a successful model of enterprise development. Ministry of Finance (2018) has stated that MEDEP has created more than 130000 micro-entrepreneurs throughout its four phases all over Nepal. According to MoEST (2019), to strengthen coordination among TEVT providers, eliminate inconsistencies in provisions, and improve the quality and scale of TEVT programs in Nepal, UNDP is the implementing partner for the Knowledge and Lifelong Learning Skills (SKILLS) program under MoEST and CTEVT. Women Entrepreneurs' Association Nepal (WEAN), a cooperative registered in 1992, is involved in 
different handicraft production (Basnet, 2001). Small and Micro Enterprise Development Programs by Federation of Nepalese Chamber of Commerce and Industry (FNCCI) and Federation of Nepalese Cottage and Small Industry (FNCSI), enterprise development activities of IEDI, Small Industries Promotion Program (SIPP/Swisscontact), Marketing linkages of Fair Trade Group (FTG) Nepal, WEAN, HAN, Trade Promotion Center (TPC) and Agro Enterprise Center (FNCCI/USAID) are some successful private sector institutions and NGOs acting for skill and enterprise development in Nepal. Intensive Banking Programs of commercial banks for CSIs and micro-finance businesses by development banks and organizations are also supporting enterprise development in Nepal (Bajracharya et al., 2005).

\section{Research Methods}

A descriptive research design has been applied in this research. Secondary data in the forms of internationally and nationally published guidelines and evaluation studies on BDS market promotion have been analyzed to describe the phenomenon. MEDEP's evaluation studies are another source of secondary data used to describe the MED model and contribution of MEDEP toward the adoption and expansion of the BDS market development approach in Nepal. For making the findings of secondary data more reliable on MEDEP's contributions to the BDS market development in Nepal, 50 BDSPOs were interviewed and requested to express their opinions. Experts' opinions were requested to be expressed in 5 points Likert scale $(1=$ Strongly Disagree and $5=$ Strongly Agree $)$. Descriptive statistical analysis is undertaken to analyze the primary data.

In Nepal, a variety of agencies are providing BDS to MSEs. DCSI, CSIDB, and CTEVT are providing BDS in the form of skill development training whereas MEDEP and other few are providing BDS components in an integrated manner (Bajracharya et al., 2005). They also have found that most BDS in Nepal focus on skill development, while only a few agencies assist MSEs in the marketing of their products and services. Financial services are not part of the BDS projects. Financing is available through different classes of banks in Nepal but most of the MSEs are found to rely on informal sources of finance. Shah (2007) finds that BDS is a nurturing process that helps to move a technical concept to its commercialization through three phases namely, entrepreneurs, enterprise, and market.

\section{Data Analysis and Results}

\section{Micro-Enterprise Development (MED) Model}

Micro-Enterprise Development Program (MEDEP) was initiated in 1998 by the Ministry of Industry with the support of UNDP to promote micro-enterprises with BDS support (Thapa \& Mathema, 2001). According to MEDEP (2017), it had named its BDS program as 'Micro-Enterprise Development (MED) for enterprise promotion. Through the MED model, various support services have been provided to entrepreneurs needed for their enterprise creation and development. Business Development Service Providers (BDSPs) are agents or consulting firms hired by MEDEP to provide enterprise creation and development supports to Micro Enterprises (MEs) on a contractual agreement basis.

Many evaluation studies have found MEDEP's efforts to promote MEs through the MED model in Nepal are very effective. MED has been recognized as an example of a good enterprise promotion model to alleviate poverty. According to Bajracharya et al. (2005), initially, MEDEP has started in three districts and ultimately reached ten districts in its first phase (1998-2003). They have also found that MEDEP's MED model is a good model for MSE development and promotion in Nepal. It has applied a holistic approach to BDS as shown in Figure 2. 


\section{Figure 2: A framework of entire MEDEP showing process and components of MED model}

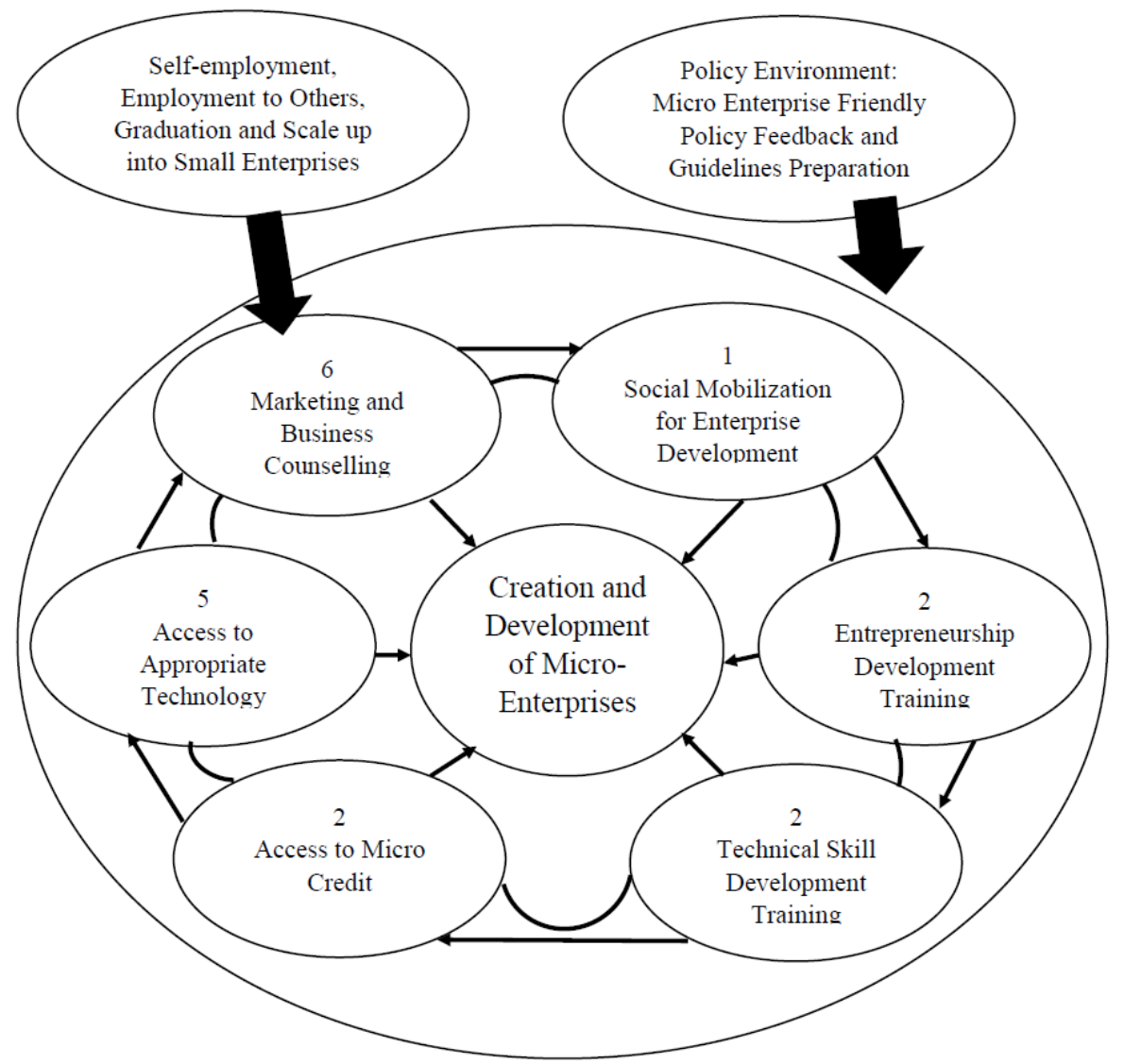

Note. From Lesson Learnt Documentation of the MED Model Promoted by MEDEP/MEDPA in Nepal (p. 22), by Rai J.K., Chapagain S.P. and Shrestha A., 2018, UNDP

The figure above indicates that the six components represent a generalization of the support requirements of micro-entrepreneurs, and the ultimate aim is to have entrepreneurs become selfsustaining and graduate. According to Khatiwada (2015), the Government has internalized the MED model of MEDEP as Micro Enterprise Development for Poverty Alleviation (MEDPA) program in 50 districts (p.97). Currently, all the MEDEP districts have been graduated to MED PA districts i.e., MEDEP has now been fully internalized by the Ministry of Industry, Government of Nepal. Altogether, 132,387 micro-enterprises have been created from MEDEP and MED PA as shown in Table 2 below.

Table 2: Phase-wise Created Micro-Enterprises

\begin{tabular}{lcccc}
\hline \multicolumn{1}{c}{ MEDEP Phases } & Male & Female & Total & $\begin{array}{c}\text { Cumulative No. of } \\
\text { District Coverage }\end{array}$ \\
\hline I (Aug 1998-2003) & 3614 & 3820 & 7434 & 10 \\
II (2004-March 2008) & 7034 & 17739 & 24773 & 25 \\
III (April 2008-July 2013) & 10603 & 26022 & 36625 & 38 \\
IV (Aug 2013-July 2018)* & 13366 & 50189 & 63555 & 75 \\
\hline Total & $34617(26 \%)$ & $97770(74 \%)$ & 132387 & 75 \\
\hline
\end{tabular}

*Note: Enterprise created under MED Model. From MEDEP database as of December 2017. 
Although the history of the BDS model for enterprise promotion is generally traced more than six decades ago, it can be seen widely used as a tool for economic development by developed as well as developing nations. Industrial Policy (2010) has also recognized BDS as one of the effective economic development and poverty alleviation tool through micro-enterprise creation and development.

\section{Contribution of MEDEP for BDS Market Development in Nepal}

Literature infers that traditional skill and enterprise support approaches lacked effectiveness as well as resulted in lower enterprise and BDS market sustainability. In this regard, MEDEP found gradually progressed in three major areas which were very necessary to fully adopt the BDS market development approach. According to various evaluation studies, MEDEP had strongly contributed to the BDS market development in Nepal through (i) demand-driven intervention approach; (ii) partnership development strategy; and (iii) supports to preparing an enabling policy environment for microenterprise development.

\section{The Intervention Approach}

Demand-driven strategy is found as an innovative approach to moving away from the short-term 'gap filling' approach towards service introduction. In their working paper, Cantel, Romijn, and De-Wildt (2003) have suggested that BDS should move towards an evolutionary approach, which is built on the recognition that service innovations evolve iteratively through continuous interaction between market parties. In this alternative model, BDS customers are no longer seen as mere buyers of services and respondents in one-shot market surveys. They co-develop and co-produce new services in partnership with suppliers.

According to McVay and Miehlbradt (2002), many have even begun to hail the model as a 'new paradigm' of small enterprises support which aims to quickly phase out initial subsidies as demand builds up as markets develop. Since the Small Enterprise clients decide which services will be offered by paying for them, the approach has been dubbed as demand-driven. MEDEP has applied a demanddriven intervention strategy from its very beginning as shown in Figure 3. UNDP (2018) has mentioned this strategy as 'a long-term visionary framework' of MEDEP. The demand-driven approach has been conceptualized and continuously practiced for the effective use of resources and the best possible outcome by MEDEP.

Figure 3: Demand-Driven Intervention Approach of MEDEP

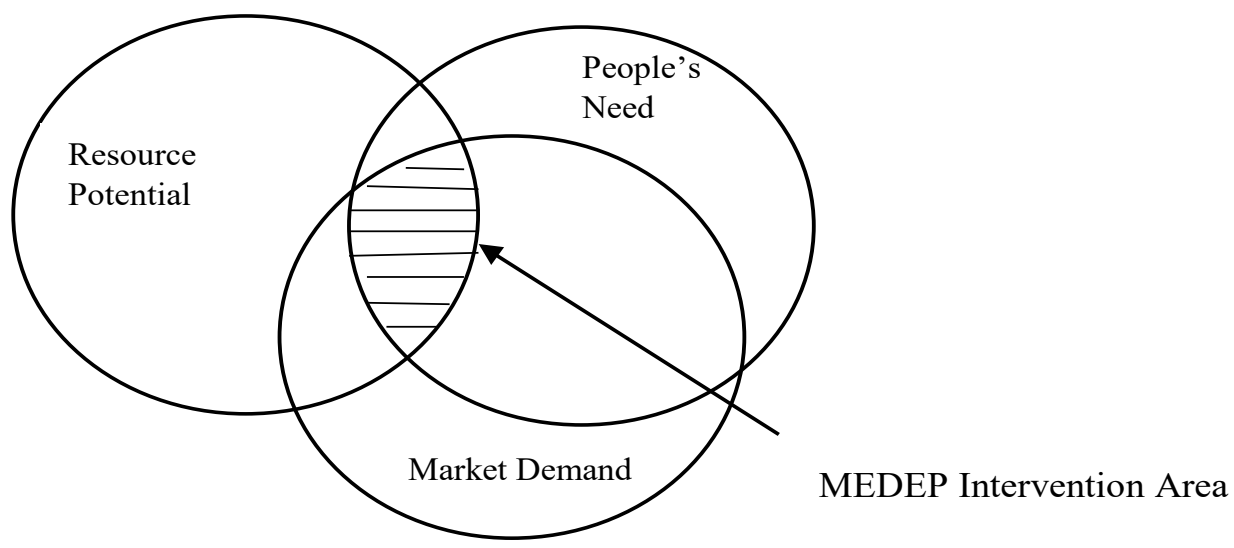

Note. The MEDEP intervention area denotes an intersection area of resource potential, peoples' needs, and market demands for micro-enterprise development. From Feasibility Study, 2001: Integrating MEDEP Modality into Mainstream Poverty Alleviation Program (p.10), by Thapa and Mathema, 2001, MEDEP 


\section{Contribution in Developing Necessary Manpower and Promotion of BDSPOs}

Enterprise Development Facilitators (EDFs) are key actors in BDS delivery mechanisms. At its very starting, MEDEP has itself trained necessary EDFs to execute the MED model due to the unavailability of necessary skilled manpower at that time. Therefore, MEDEP had to use the traditional approach i.e., direct intervention in BDS supply through its regular employees. Gradually, MEDEP started to promote its trained staffs to work as independent BDSPOs. In their evaluation report, Huntington et al. (2006) have also well-acknowledged MEDEP's efforts in transforming the local salaried employees into local independent BDSPOs.

MEDEP (2009) stated that it promoted many BDSPOs capable of independently serving the BDS market. Similarly, other NGOs and private institutions were also gradually attracted to this field. Such improvements have made the BDS sector an attractive profession MED program now has the opportunity to hire BDSPOs on the competitive bidding process. Result Based Sub-contracting (RBSC) approach applied by MEDEP while contracting BDSPOs is itself considered as a paradigm shift in the government's development approach that has helped to increase the outreach of government's development efforts (Rai et al., 2018).

MEDEP (2017) has stated that it is continuously developing EDFs through linkages with CTEVT and 1,234 EDFs have already been developed as of December 2017 and utilized for MED implementation. Altogether 26 private training institutes affiliated with CTEVT are contributing to train and produce EDFs in the market (Rai et al., 2018, p. 79). This data infer a good sign of developed BDS market in Nepal.

GBPP (2018) has stated that EDF development is provisioned through (i) academic courses like 18 months TSLC and Three Year Diploma in Entrepreneurship Development; and (ii) Level 2 and Level 3 Skill Testing under NSTB of the CTEVT. According to GBPP (2018), in its initial periods, MEDEP had to provide scholarships to attract students to join the EDF course but now people are attracted to the BDS profession.

\section{$>\quad$ Partnership Building Strategy for BDS Delivery}

Showing the importance of institutional partnership and alignment, Eiligmann (2005) has mentioned that public services can be delivered cost-effectively and sustainably by partnering with private sectors. According to Khatiwada (2015), MEDEP's working modality in partnership has generated synergies to the program. MEDEP had given priority to the formation of ME groups, associations, and cooperatives as well as focused on their capacity development. The ultimate objective behind the capacity building of local-level institutions is to develop them as capable working partners. Figure 4 depicts the overall MEDEP implementation strategy to develop a sustainable enterprise partnership.

Figure 4 shows how MEDEP designed its overall program implementation strategy to achieve a sustainable enterprise partnership keeping the demand-driven approach at its central point. The program implementation cycle depicted in Figure 1 indicates that the needs of poor families may change once they come out of the poverty level. They create new demands in the market. New needs arise in the market. In that situation, the creation of institutional mechanisms and their capacity development will certainly enhance the market's capacity to fulfill such new demands from MEs. In this way, an enterprise partnership cycle will be continued sustainably among buyers and sellers of BDS.

Till the end of its 2nd phase in 2008, MEDEP had prepared a strong local level base for program implementation that complied with the market development approach. According to UNDP (2008), MEDEP executed its BDS activities in partnership with District Development Committees (DDCs) from the very beginning. UNDP (2014) stated that MEDEP finally was able to develop a successful approach to MED that would certainly enhance BDS market sustainability in Nepal. UNDP's report indicates how MEDEP successfully switched its MED intervention approach from direct to indirect. 


\section{Figure 4: MEDEP Implementation Strategy}

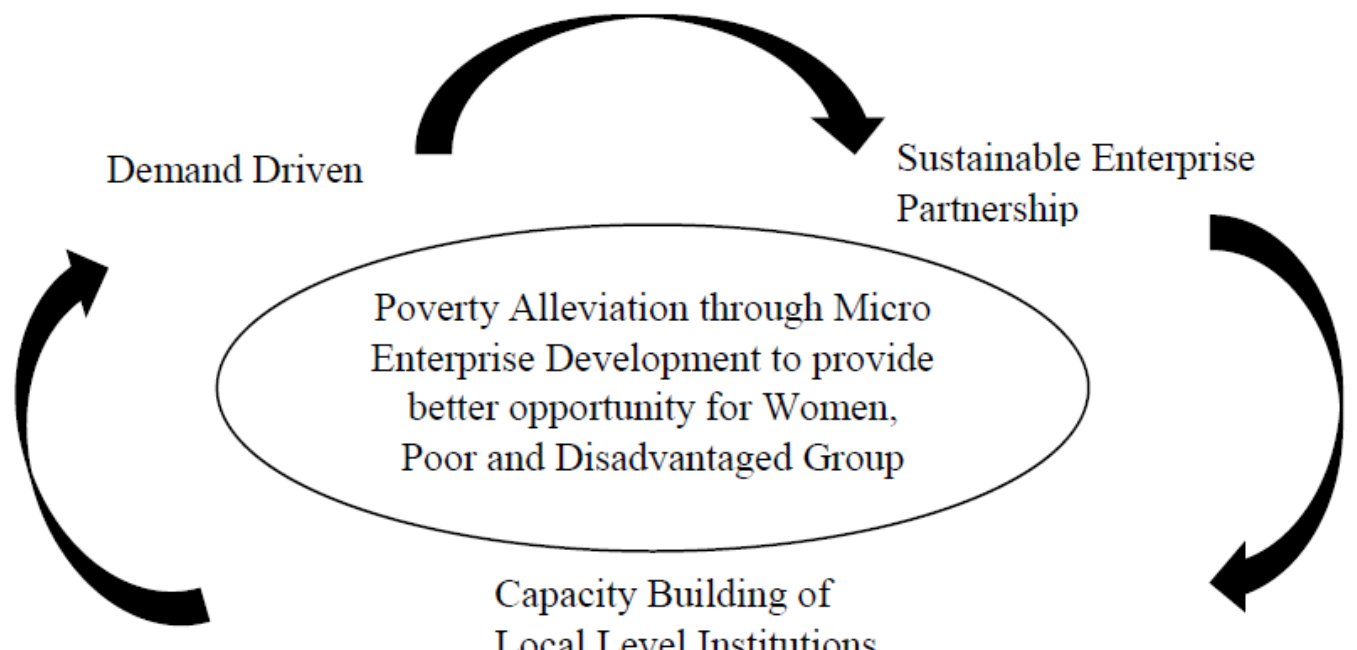

Note. Overall implementation strategy of MED program. From Desktop Manual, Micro-Enterprise Development Program Implementation Process (p. 3), by MEDEP, 2017

Improved private sector institutional linkages may also improve marketing and enhance access to finance. Despite various efforts of MEDEP for institutional capacity development; Bajracharya and Joshi (2005) found limited linkage of MSEs with formal private sector institutions. They have stated that linkages of MEDEP entrepreneurs with the private sector appeared to be occurring in a diversified manner only. Narma Consultancy (2010) has revealed that, although MEDEP is successful in creating several institutions from the central to grassroots levels, they are lacking sustainability. The MED components and developed partnership modality for its implementation are presented in Table 3 below.

Table 3: MED Major Steps and Gradually Developed Stakeholders for Implementation

\begin{tabular}{|c|c|c|c|c|}
\hline Steps & $\begin{array}{c}\text { Key Action/Sub- } \\
\text { steps }\end{array}$ & $\begin{array}{c}\text { Key } \\
\text { Responsible } \\
\text { Entities }\end{array}$ & $\begin{array}{l}\text { Supporting } \\
\text { Agencies }\end{array}$ & Participants \\
\hline \multirow{3}{*}{$\begin{array}{l}\text { Identification of } \\
\text { Program Location } \\
\text { and Market Centers }\end{array}$} & $\begin{array}{l}\text { Resource Potential } \\
\text { Survey }\end{array}$ & MEDEP & Consultants & DDC \\
\hline & $\begin{array}{l}\text { Triangulation of } \\
\text { Findings }\end{array}$ & MEDEP & $\begin{array}{l}\text { District } \\
\text { stakeholders }\end{array}$ & $\begin{array}{l}\text { District } \\
\text { stakeholders }\end{array}$ \\
\hline & $\begin{array}{l}\text { Selection of } \\
\text { market centers and } \\
\text { program location }\end{array}$ & $\mathrm{DEDC} / \mathrm{DDC}$ & $\begin{array}{l}\text { MEDEP } \\
\text { consultant }\end{array}$ & $\begin{array}{l}\text { District } \\
\text { stakeholders }\end{array}$ \\
\hline \multirow{2}{*}{$\begin{array}{l}\text { Identification } \\
\text { of Potential } \\
\text { Entrepreneurs }\end{array}$} & Poverty Mapping & MEDEP & $\begin{array}{l}\text { BDSPO, } \\
\text { DDC, VDC }\end{array}$ & $\begin{array}{l}\text { Local Communities } \\
\text { (LCs) }\end{array}$ \\
\hline & $\begin{array}{l}\text { Surveys (Form } \\
\text { A,B,C) }\end{array}$ & MEDEP & BDSPO & LCs \\
\hline
\end{tabular}




\begin{tabular}{|c|c|c|c|c|}
\hline Steps & $\begin{array}{c}\text { Key Action/Sub- } \\
\text { steps }\end{array}$ & $\begin{array}{c}\text { Key } \\
\text { Responsible } \\
\text { Entities } \\
\end{array}$ & $\begin{array}{l}\text { Supporting } \\
\text { Agencies }\end{array}$ & Participants \\
\hline \multirow{4}{*}{$\begin{array}{l}\text { Establishment of } \\
\text { micro-entrepreneurs }\end{array}$} & & MEDEP & $\begin{array}{l}\text { BDSPO, } \\
\text { DDC, VDC }\end{array}$ & $\begin{array}{l}\text { LCs, Potential HHs } \\
\text { and Entrepreneurs }\end{array}$ \\
\hline & Survey form D & MEDEP & BDSPO & Traders \\
\hline & $\begin{array}{l}\text { Orientation } \\
\text { training }\end{array}$ & MEDEP & BDSPO & $\begin{array}{l}\text { Potential } \\
\text { Entrepreneurs } \\
(\mathrm{PEs})\end{array}$ \\
\hline & SIYB & MEDEP & BDSPO & PEs/Entrepreneurs \\
\hline \multirow{5}{*}{$\begin{array}{l}\text { Follow-up } \\
\text { support services } \\
\text { and technical } \\
\text { backstopping }\end{array}$} & $\begin{array}{l}\text { Group and } \\
\text { Association } \\
\text { Formation (Social } \\
\text { Mobilization) }\end{array}$ & $\begin{array}{l}\text { MEG/MEGA/ } \\
\text { DMEGA/ } \\
\text { NMEGA }\end{array}$ & MEDEP & $\begin{array}{l}\text { Micro- } \\
\text { entrepreneurs }\end{array}$ \\
\hline & Skill Training & BDSPO & $\begin{array}{l}\text { MEDEP/ } \\
\text { DCSI/DDC }\end{array}$ & \\
\hline & Finance Services & MFIs/Banks & $\begin{array}{l}\text { BDSPO/ } \\
\text { DMEGA }\end{array}$ & \\
\hline & $\begin{array}{l}\text { Technology } \\
\text { Services }\end{array}$ & BDSPO & $\begin{array}{l}\text { MEDEP/ } \\
\mathrm{DDC} / \mathrm{VDC} / \\
\mathrm{DCSI}\end{array}$ & \\
\hline & $\begin{array}{l}\text { Marketing linkages } \\
\text { and business } \\
\text { counseling }\end{array}$ & DMEGA & $\begin{array}{l}\text { MEDEP/ } \\
\text { DCCI/ } \\
\text { FNCCI/ } \\
\text { BDSPO/ } \\
\text { NMEGA }\end{array}$ & $\begin{array}{l}\text { Micro- } \\
\text { entrepreneurs } \\
\text { traders }\end{array}$ \\
\hline
\end{tabular}

Note. From Impact Assessment of Micro-Enterprise Development Program by Narma Consultancy, 2010, MEDEP

Table 3 shows that MEDEP's support is directed towards the delivery of skill and technical support services. It does not provide direct cash or other material supports to MEs. But it assists them to make linkages with MFIs. According to Narma Consultancy (2010), it provides some hardware (equipment, tools, machinery, and building) supports through the provision of common facility centers (CFCs). Support for CFCs, particularly, building construction part is not provided unless the MEs receive assistance through local bodies i.e. municipalities, VDCs, DDCs, and other donor agencies. So, from the data in Table 3, MEDEP's role could be seen as a facilitator only. It is vital for adopting the market development approach to BDS. Table 3 shows that direct BDSPOs from private and NGO sectors are assigned to deliver BDS components to MEs.

\section{$>\quad$ Policy Level Contribution of MEDEP}

Thapa and Mathema (2001) have mentioned that prior to MEDEP, even a formal definition of MicroEnterprise was not available in Nepal. In their MSE Policy Review in Nepal, Bajracharya et al. (2005) stated that existing information on MSEs was found to be inadequate, fragmented and spread across several organizations (p. viii). As UNDP (2014) stated, 'MEDEP has successfully provided policy advocacy for the promotion of MSEs, and supported to draft appropriate policies, acts, regulations, and guidelines within those 16 years of its implementation. According to MEDEP (2015), more than 30 policies, regulations, guidelines, and programs in Nepal, directly and indirectly, have recognized 
the issues of MEs, and of them, many have recognized the MED model as a tool for entrepreneurship development. MEDEP can be highly credited in formulating many such policies and guidelines which are very crucial to preparing an enabling policy level environment for the micro-enterprise promotion and BDS market.

\section{Primary Data Analysis and Results}

As an effort to triangulate findings on MEDEP's contributions to promote the BDS market in Nepal from secondary sources, the calculated mean values of some relevant questions from BDS experts have been presented in Table 6 below.

Table 6: Mean Value of Experts' Opinion

\begin{tabular}{lll}
\hline S.N. & Questions & Mean \\
\hline 1 & EDFs' have a determinant role in delivering BDS successfully & 4.73 \\
2 & $\begin{array}{l}\text { Recognition of BDS as an important tool for micro-enterprise development in } \\
\text { Nepal is at the top of MEDEP's contribution }\end{array}$ & 4.67 \\
3 & $\begin{array}{l}\text { MEDEP has contributed to developing sufficient policies and guidelines for } \\
\text { promoting the BDS market in Nepal }\end{array}$ & 3.87 \\
4 & $\begin{array}{l}\text { MEDEP's strategy for institutional capacity development has contributed to the } \\
\text { formation of local to national level partners institutions for BDS implementation }\end{array}$ \\
5 & $\begin{array}{l}\text { MEDEP should entirely be credited for the crowding in of BDSPOs in the market } \\
6\end{array}$ & $\begin{array}{l}\text { Lack of institutional focus is a challenge faced for the sustainability of micro- } \\
\text { enterprise associations }\end{array}$ \\
7 & $\begin{array}{l}\text { Active stakeholder relationship could not be established yet to an effective BDS } \\
\text { delivery by MEDEP }\end{array}$ & 4.28 \\
8 & $\begin{array}{l}\text { The effectiveness of BDS delivery highly depends upon the institutional capability } \\
\text { of BDSPOs }\end{array}$ & 4.82 \\
9 & $\begin{array}{l}\text { Implementation of the Result Based Sub-Contracting (RBSC) is a milestone for } \\
\text { program effectiveness }\end{array}$ & 4.69 \\
10 & $\begin{array}{l}\text { Community Facility Centers (CFCs) created by MEDEP should be further } \\
\text { promoted as Incubation Centers for hardcore poor entrepreneurs }\end{array}$ \\
11 & $\begin{array}{l}\text { The smooth functioning of MED activities are always challenged by frequent } \\
\text { transfer of related staff officials }\end{array}$ & 4.67 \\
\hline
\end{tabular}

Note. Analyzed from Survey Questionnaire

Question1 is related to how EDFs are important players in the delivery of quality BDS. The mean value at 4.73 infers that almost all experts strongly agree that EDFs play a determinant role in BDS delivery. It infers that the quality of EDFs also equally matters. Questions 2 to 5 are related to MEDEP's contributions in the establishment of BDS models and markets in Nepal by supporting to development of necessary policies and guidelines; institutional frameworks; and developing an attractive BDS market. The mean values for all questions are above the average inferring that experts agree on MEDEP's creditable contributions in such areas. Question 6 shows that experts see a lack of institutional focus in MEDEP created enterprise associations and agree that it is a big challenge for their self-sustainability. Maybe this is the reason for having not properly established active stakeholder relationships as agreed by experts in question 7 .

From question 8, almost all experts strongly agree that BDSPO's institutional capability highly matters for quality BDS delivery that's why they also strongly agree that a result-based sub-contracting system is a very useful parameter for ensuring quality performance from BDSPOs in question number 9. 
From question number 10, almost all experts strongly agree that MEDEP created infrastructures; for example; community facility centers should be preserved and further promoted for better use in the future. Since MEDEP has been fully graduated under MED PA which is entirely under the bureaucratic institutional framework. In this respect, the frequent transfer of program-related government officials can be one of the never-ending challenges causing MED activities to be executed intermittently as strongly agreed by most of the experts.

\section{Conclusion}

From the study of the MED model, we can see that it has followed the enterprise creation and development process very well. The MED process has tried to properly address necessary issues related to all the growth stages of an enterprise. Skill and enterprise development models should be well aligned with the utilization of available natural resources; income generation and lifestyle expectation of people; issues related to climate changes; producing quality products and services; enhancing export market and sustainable enterprise practices. From the analysis of the demand-driven intervention approach and strategies applied for BDS market promotion and sustainability, we can conclude that the MED model has followed international best practices, properly designed, and appropriately contextualized in Nepal.

Within 20 years of the program implementation period, MEDEP found played a crucial role to introduce and expand the BDS market in Nepal. During its entire program period, the contributions of MEDEP are highly appreciable in developing institutional setups, skill human resources, and policies and guidelines to follow the market development approach for developing a sustainable BDS market in Nepal. Conclusively, MEDEP was found successful to transform its role of a BDSPO (direct business service provider) to a facilitator which is a key requirement of the market development approach.

It can be undoubtedly said that MEDEP successfully expanded the BDS model and market in Nepal (started from 10 districts and going to be extended in all 753 LGs soon). Many public and private institutions in Nepal have started to replicate the components of the MED model. Now, it rests upon the Ministry of Industry and the Government of Nepal to keep up the best practices established by MEDEP to promote micro-enterprises and the BDS market. For further improvement in the BDS market and sustainability, MED PA must act upon incorporating the findings from GBPP (2018) to ensure the production of quality EDFs, since they have a determinant role while delivering BDS. Similarly, since MED PA is going to implement the MED model in all 753 LGs, it should consider applying necessary flexibilities on the market development approach as the literature suggested that full adoption of market development approach depends upon the socio-economic context of a particular area and the kind of services to be promoted.

\section{Conflict of Interest}

There is no conflict of interest in preparing this paper.

\section{References}

Acharya M.; Mathema P. and Acharya B. (1999). Women in Nepal. Asian Development Bank.

Alliance for Social Mobilization (2009). capacity assessment and institutional development guidelines for MEDEP supported organizations. MEDEP, Lalitpur

Altenburg, T. and Stamm, A. (2004). Toward more effective provision of business services. German Development Institute, Bonn

Bajracharya, P.; Pant, D.P.; White, S.; and Joshi, G. (2005). A report on micro and small enterprise policy review in Nepal. ILO, Geneva

Basnet, S. (2001). Women in handicraft production of Kathmandu City in Nepal. An unpublished PhD Thesis, University of North Bengal, Darjeeling 
Berisha. G. and Puta. J. S. (2015). Defining small and medium enterprises: A critical review. Academic Journal of Business, Administration, Law and Social Sciences, Vol 1, \#1, pp. 17-28

CDASED (1998). Business development services for SMEs: Preliminary guidelines for donor-funded interventions. Author

CDASED (2001). Business development services for small enterprises: Guiding principles for donor intervention. Author

Churchill and Lewis (1983). Growing Concern: The Five Stages of Small Business Growth. Harvard Business Review

Davis, C. H. \& Vladica, F. (2005). Demand for e-business support services among New Brunswick SMES. Atlantic Canada Opportunities Agency (ACOA) pdfs.semanticsholar.org/9957/ a79dc9d477c0f032de88c863b15db78c20d6.pdf

Development Resource and Training Center (2015). Mass impacts on entrepreneurs of selected products and services promoted by Micro-Enterprise Development Program. MEDEP, Lalitpur

Eligmann, A. (2005), Making business development services markets work for the poor. Deutsche Gesellschaft Fur (GTZ)

GBPP (2018). Assessment of effectiveness of enterprise development facilitators (EDFs) in service delivery and training institutes in conducting training of EDF course. MEDEP, Lalitpur

Goldmark, Lara (1996). Business development services: A framework for analysis. Inter- American Development Bank, Washington, DC

Goyal, S.; Sergi B.S. and Esposito, M (2015). Business development services for micro, small and medium enterprises-literature review of past trends and future directions. World Review of Entrepreneurship Management and Sustainable Development. Vol. 14, No. 3, 312-332, Inderscience Enterprises Ltd.

Gurung, M.M. (1999). Training programs for development of micro-enterprises in the cottage and small sector in Nepal. ICIMOD, Kathmandu

Gyawali, K. (2014). Development of industrial sector in Nepal: Perspective and challenges, Ministry of Industry, Kathmandu

Huntington, R.; Bajracharya, P., Thakali, H. and Basyal, H.P. (2006). Micro-enterprise development program (MEDEP) Phase II: Mid term review, MEDEP, Lalitpur

Kafle, A. P. (2007). Workforce Development in Nepal: Policies and Practices. Asian Development Bank Institute, Tokyo, Japan

Khatiwada, Y. K. (2015). Internalization of MEDEP into MEDPA: An opportunity and some issues. Ministry of Industry, Kathmandu

Khatri, M. B. (2018). Industrial development in Nepal: Problems and prospects. The Economic Journal of Nepal, Vol. 41, No. 3\&4, Issue No. 150, pp. 25-40, Cedecon-TU.

MEDEP (2005). Consolidated progress report - 1998-2003. Author, Kathmandu

MEDEP (2009). Capacity assessment and institutional development guidelines for MEDEP supported organizations. Author, Lalitpur

MEDEP (2017). Desktop manual. Author, Lalitpur

Miehlbradt, A.O. and McVay, M. (2003), Developing commercial markets for business development services: BDS primer. ILO, Italy

Ministry of Education, Science and Technology (2019). Comprehensive TVET annual report-2075. Singhadurbar, Kathmandu: Author

MoF (2018). Development partners' profiles. Author, Kathmandu

MoI (2010). Industrial Policy - 2010. Author, Kathmandu

Norma Consultancy (2010). Impact assessment of microenterprise development program. MEDEP, Lalitpur.

OECD (2017). "Enterprises by size”, in entrepreneurship at a glance 2017, OECD Publishing, Paris.

Rai, J. K.; Chapagain, S. P. and Shrestha, A. (2018). Lessons learned documentation of the MED model promoted by MEDEP/MEDPA in Nepal. UNDP, Lalitpur 
Ranabhat, B.R. (2007). Entrepreneurship development for competitive SMEs: Development strategy and overview. Entrepreneurship Development for Competitive Small and Medium Enterprises. Asian Productivity Organization, Japan

Rijneveld, W. (2006). Business development services: A sector analysis. Woord en Daad

Shah (2007). Business incubation in Nepal: A survey on supply and demand of incubation services. A Master Degree Dissertation submitted to AIT, Thailand

Singdel, M. (2015). Role of Department of Cottage and Small Industry in Women Enterprise Development Program in Nepal. PYC Nepal Journal of Management, Vol. VI-VIII, \# 1

Thapa, P. K. \& Mathema, S. R. (2001). Feasibility study of integrating MEDEP modality into Mainstream National Poverty Alleviation Program. MEDEP, Lalitpur

UNDP (2004). Business development services: How to Guide. Bratislava Regional Center, UNDP

UNDP (2008). Project document: Phase III. Author, Kathmandu.

UNDP (2013). Project document: Phase IV. Author, Kathmandu.

UNDP (2015). Annual report-2015. Author, Kathmandu

UNDP (2018). Economic analysis of micro-enterprises in Nepal. Author, Kathmandu 